\title{
Relationship between fiscal deficits and unemployment in South Africa
}

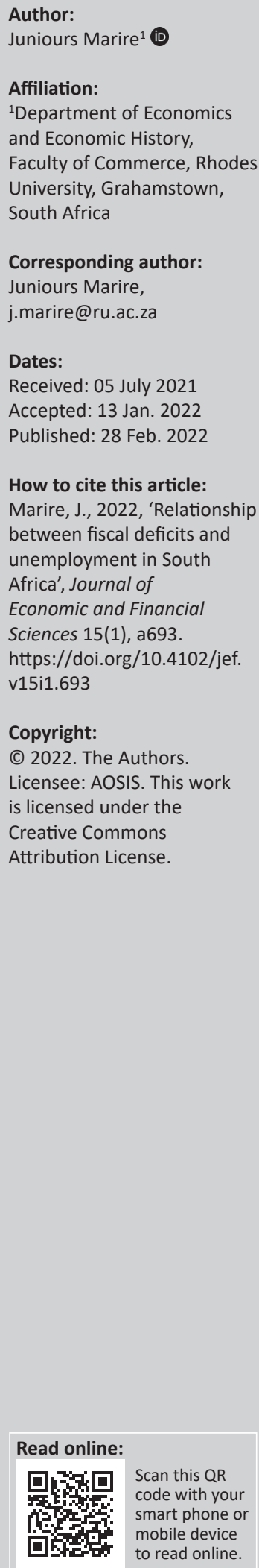

Orientation: Heterodox economic scholarship has challenged the neoclassical doctrine that fiscal deficit increases unemployment in the long-term.

Research purpose: This article examined the relationship between fiscal deficits and unemployment.

Motivation for the study: The renewed debate about the role of fiscal consolidation in controlling unemployment in South Africa motivated the study. Neoclassicists in South Africa maintain that fiscal consolidation is the solution to unemployment, while heterodox thinkers argue for active fiscal policy.

Research approach/design and method: The study utilised the Toda-Yamamoto Granger noncausality test and the Autoregressive Distributed Lag Modelling framework to test the relationship between unemployment and fiscal deficit. The quarterly data for the period 1994-2019 were obtained from the South African Reserve Bank.

Main findings: This study found that fiscal deficits reduce unemployment in the short- run but increase it in the long run, thus confirming the neoclassical claim.

This study found no statistical evidence for the heterodox view that fiscal deficits reduce interest rates and the neoclassical crowding-out hypothesis. Rather, the interest-neutrality of fiscal deficits was found. The adoption of a fiscal belief system that builds on the expansionary fiscal contraction hypothesis has been associated with high unemployment.

Practical/managerial implications: Fiscal authorities have to use fiscal deficits creatively in managing unemployment to create a balanced economy. The fiscal balance, up to a threshold, between $0.8 \%$ (surplus) and $1.9 \%$ (deficit) of gross domestic product (GDP) in the short term and between $1.7 \%$ (deficit) and 1.9\% (deficit) in the long term reduces unemployment as per the estimates of the study.

Contribution/value-add: The finding that fiscal deficits increase unemployment does not justify a weak fiscal policy stance. The finding that fiscal deficits reduce unemployment up to a point before they begin to increase it in the long-term complements existing literature, which shows that South Africa's government expenditure to GDP ratio has exceeded its optimal level.

Keywords: crowding-out hypothesis; fiscal consolidation; fiscal deficit; Kaleckian thought; Keynesian thought; Modern Monetary Theory; Ricardian equivalence; unemployment.

\section{Introduction}

Inequality, poverty and unemployment are the most stubborn economic problems South Africa is facing, and unemployment seems to be foundational to the other two (Simkins 2004). Finding the correct mix of policies that can reduce unemployment remains elusive. Among the youth, unemployment has been rising significantly. The government instituted a youth wage subsidy (National Treasury [South Africa] 2011), which has not delivered the much-needed jobs (Levinsohn \& Pugatch 2014). The government instituted extended public works, some of which are in the care economy, which go beyond general infrastructure provision jobs (Altman \& Hemson 2008). The Working for Water Programme, which is also part of the extended public works programme, creates green jobs while conserving biodiversity and promoting water security (Magadlela \& Mdzeke 2004). Other public works programmes have been running for years, but unemployment remains problematic (Altman \& Hemson 2008; Thwala 2011).

The purpose of the study is to test the effect of budget deficits on unemployment in South Africa. Scholars, politicians and policymakers in South Africa are grappling with rising levels of 
unemployment, and the proposed solutions to the problem are as diverse as there are proponents. Expansionary fiscal contraction is yet to deliver jobs and unemployment continues to rise. Voices from the left in the constitutional political economy of South Africa advocate bold fiscal policy decisions that increase deficits in the interest of creating employment and a balanced economy that works for all. Conservative voices blame a slow fiscal consolidation process and unbalanced fiscal books as causes of unemployment, among other causes (Burger \& Calitz 2020; Burger, Siebrits \& Calitz 2016). The causal relationship between unemployment and budget deficits remains empirically unexamined in South Africa. The study sets out to test Neoclassical and Heterodox theoretical postulates on the relationship between deficits and unemployment using South African data.

Since the dawn of democracy, and the subsequent adoption of the Medium Term Expenditure Framework (MTEF) in 1997-1998 and its drive towards fiscal consolidation, falling budget deficits coexisted with rising unemployment (see Figure 1, the period 1994-2003). Periods of fiscal surpluses coincided with rising unemployment in general. The general view is that in the short run, fiscal consolidation is associated with rising unemployment, but in the long run, it will create fiscal space in areas where capital expenditure is allocated. Burger et al. (2016:501) have shown that the fiscal consolidation process of the period 1996 to 2008 came at the cost of falling capital expenditure, and so, 'fiscal sustainability might have been restored, but government's balance sheet did not improve'. This puzzling trend raises questions about the efficacy of fiscal consolidation in reducing unemployment in South Africa. This is an important policy and intellectual issue to address. The period 1994-2003 coincides with the Growth, Employment and Redistribution (GEAR) policy era. After 2003, a positive correlation between deficits and unemployment is evident. Rising fiscal deficits coexisting with rising unemployment suggest that the quality of fiscal spending has been deteriorating (Burger 2014). Wasteful fiscal spending limits the effectiveness of fiscal deficits in delivering employment.

The trends in Figure 1 are puzzling and seem to suggest a regime shift in the relationship. The project on fiscal consolidation, which began in the GEAR era, promised to create fiscal space for the government to reallocate resources to longterm investment that would improve the productivity of the economy and its labour absorption capacity (Burger \& Calitz 2019; Burger et al. 2016; Calitz \& Siebrits 2003). The picture depicted in Figure 1 suggests that fiscal consolidation, among other factors, delivered unemployment (Alenda-Demoutiez \& Mügge 2020; Hirsch \& Hines 2005; Padayachee 2006). Elson (2013), Watts and Sharpe (2013), Kelton (2015) and Sawyer (2020) maintain that fiscal consolidation always and everywhere generates unemployment and compounds fiscal deficits. The idea in the critique is that fiscal consolidation undermines growth and tends to worsen debt dynamics, whereas expansionary fiscal policy stimulates growth, employment, tax revenue and promotes fiscal sustainability (Ribeiro \& Lima 2019; Uxó, Álvarez and Febrero 2018; Watts \& Sharpe 2013).

The years after GEAR were associated with both rising unemployment and budget deficits, suggesting poor deployment of deficits in the economy. Rent-seeking and state capture undermined the quality of public spending (Bhorat et al. 2017; Burger 2014). Consequently, rising government expenditure became associated with low labour absorption capacity and productivity. Schoeman and Blaauw (2009:87) found persistently high unemployment to be unresponsive to periods of favourable economic growth, to be separated from economic reality and to have a 'life of its own'. They maintained that unemployment in South Africa exhibited a strong path dependence behaviour perpetuated by policy uncertainty and information asymmetries. Unemployment in South Africa is endogenously determined in the labour market (Schoeman \&

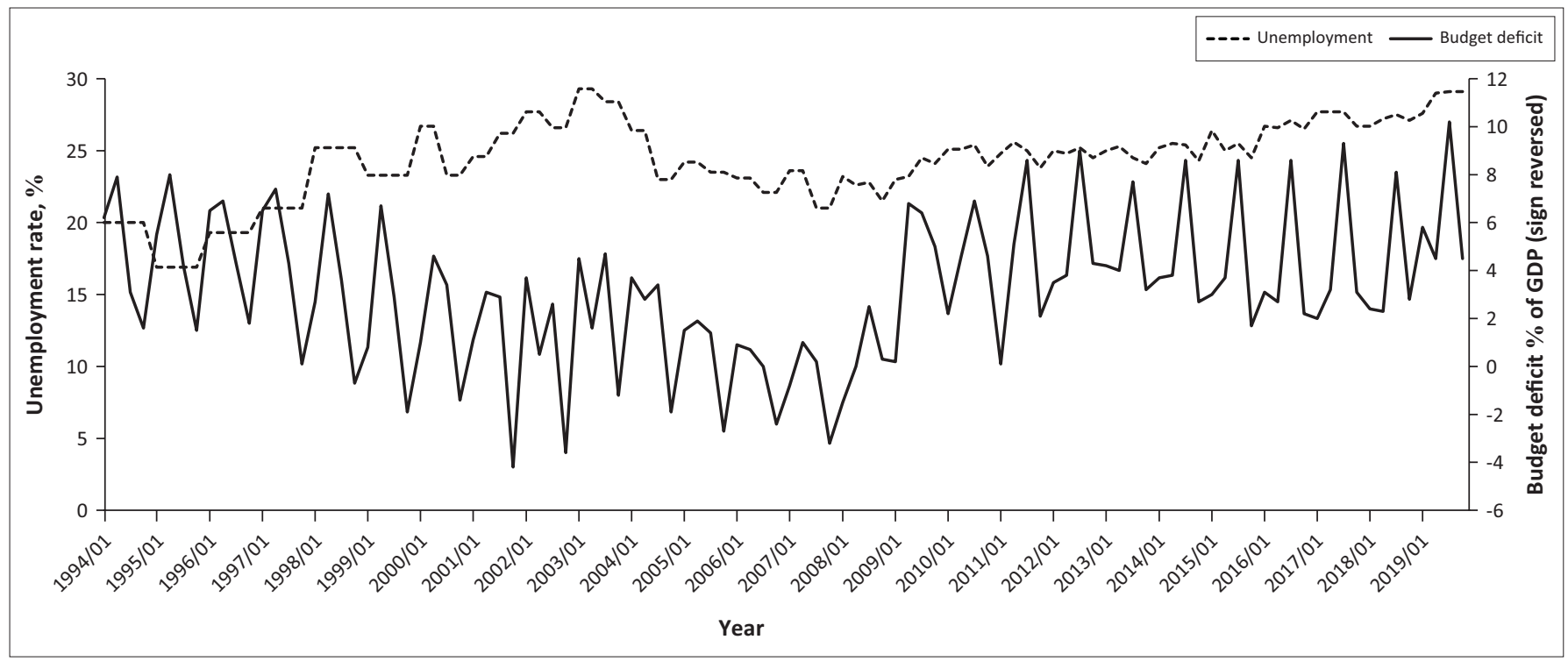

Source: Adapted from South African Reserve Bank, viewed 06 December 2020, from https://www.resbank.co.za/en/home/what-we-do/statistics/releases/online-statistical-query FIGURE 1: Unemployment and budget deficit in South Africa 1994Q1-2019Q4. 
Blaauw 2009). Hence, only external intervention could disrupt the persistent long-run labour market disequilibrium.

Banerjee et al. (2008) explained that rising unemployment between 1994 and 2003 indicated structural labour market disequilibrium, characterised by skill intensification and rising capital intensity in the private sector. Only government intervention, they said, could reduce structural unemployment. Ferreira and Rossouw (2016) also found rising capital-labour ratios since 1994, suggesting rising capital intensity. Kingdon and Knight (2007) and Kingdon and Knight (2004) found that stubborn unemployment levels in South Africa were involuntary, and they maintained that expanded public works programmes could deliver the jobs if designed optimally. Analysis by Banerjee et al. (2008) suggests that the peak of unemployment in the early 2000s is the long-run equilibrium level of unemployment in South Africa, which labour market forces cannot reduce. Because private sector employment is a function of profitability and business cycles, market-determined employment will leave masses without jobs. Creative use of fiscal policy provides the way out of unemployment.

\section{Literature review}

\section{The neoclassical link between fiscal deficit and unemployment}

Neoclassical thought postulates a positive effect of budget deficits on unemployment. Assuming far-sighted individuals who plan lifetime consumption and savings according to the Modigliani life cycle hypothesis, a rise in budget deficits creates future tax burdens while raising current consumption (Bernheim 1989). If, and it is a big IF, the economy is at full employment, savings decrease and real interest rates increase to rebalance investment and savings. The result is that deficit financing of government spending ultimately crowds out private-sector jobs, thereby increasing unemployment (De Leeuw \& Holloway 1985; Mahadea \& Simson 2010; Salsman 2017). The transmission mechanism is such that fiscal deficits lead to increases in interest rates, which in turn lead to reduced planned investment and capacity utilisation and increases unemployment.

Economists have been debating extensively the effect of budget deficits on the economy. Barro (1989) offered a Ricardian explanation of budget deficits and concluded that the neoclassical account was incorrect. He showed that an increase in budget deficits generated an offsetting increase in private savings, thus leaving real interest rates and investment unchanged. By extension, therefore, unemployment would not have to increase insofar as budget deficits, in the long term, do not crowd out private investment and erode the capital stock. Darrat (1989) found that fiscal deficits did not cause real interest rates to increase and, thus, did not crowd out private investment. Evans (1985) came to a similar conclusion for the US economy, finding that the Ricardian explanation of interest neutrality of fiscal deficits held, while Choi and Holmes (2014) found the US economy to switch between the Ricardian interest neutrality of budget deficits and the neoclassical positive effect of fiscal deficit on interest rates. A study of subSaharan African economies also found the Ricardian claim that interest rates are non-responsive or neutral to changes in fiscal deficits to hold (Kelikume 2016). Akinboade (2004) also found fiscal deficits to have no effect on interest rates in South Africa, while Bonga-Bonga (2012) found budget deficits to have a positive effect on long-term interest rates. Akinboade (2004) tested the relationship on all kinds of nominal interest rates and the relationship was robust.

Several studies found budget deficits to increase unemployment both in the short term and in the long term, especially if they exceeded the limit suggested by the cyclically adjusted budget balance (De Leeuw \& Holloway 1985; Fedeli, Forte \& Ricchi 2015). Lama and Medina (2019) demonstrated that fiscal consolidation, coupled with rising total factor productivity and rigid wages, would reduce unemployment while lowering the budget deficit. Findings such as these support the drive towards fiscal consolidation as a means of creating fiscal space that enables the government to free up resources that the economy can reallocate to binding constraints in the economy (Burger \& Calitz 2019; Burger et al. 2012, 2016). The expansionary fiscal contraction hypothesis requires the government to unlock resources by rationalising its recurrent expenditures and reallocating saved resources to capital spending for economy-wide longterm productivity. The civil service wage bill and, thus, public sector employment become the focal point for fiscal consolidation. Rising budget deficits, in this case, undermine fiscal sustainability. According to Calitz and Siebrits (2003), the general belief among economists and policymakers in South Africa in the 1990s and indeed to this day is that the best contribution of fiscal policy to overall macroeconomic stability and sustainable growth is through the stabilisation of public finances. Sound finance principles became dominant since the 1990s.

\section{The heterodox link between fiscal deficit and unemployment}

From a non-Ricardian viewpoint, Eisner (1989) critiqued mainstream economic discourses that were quick to make budget deficits a scapegoat for many macroeconomic problems, not least rising interest rates, rising unemployment, decreasing private savings and inflation, among others. His concern was that incorrect theoretical postulations or ideological commitments that were clothed with the robe of economic theory gained a foothold in the habits of thought of policymakers. Eisner (1989) established empirically that deficits reduced unemployment in the United States of America and that all periods of budget surplus were associated with rising unemployment. His findings established that fiscal deficits crowded-in private investment and jobs.

Eisner (1989) rejected Robert Barro's Ricardian approach to budget deficits arguing that an increase in aggregate expenditure today because of budget deficits did not necessarily lead to tax increases in the future but rather increased investment, incomes and, ultimately, tax revenue. 
For as long as the economy is below full employment, budget deficits use up idle real resources (slack) in the economy, which means deficits do not induce increases in interest rates and so do not crowd out private investment. His approach focused on real resources in the economy as the constraining factor. He emphasised that there was a potential risk that governments could keep budget deficits too small to be optimal, with the risk of inducing recessions or economic stagnation. Eisner (1989) equally pointed out that budget deficits became a problem whenever they became so large that they began to induce inflationary pressure on the economy. This happened when real slack in the economy was used up.

Heterodox thought, especially Modern Monetary Theory (MMT), postulates that fiscal deficits reduce unemployment. The transmission mechanism is such that deficits create public sector jobs, incomes and savings and inject liquidity into the economy, which lowers real interest rates, which in turn encourage private investment spending and, thus, create additional jobs in the private sector (Arestis \& Sawyer 2010; Kelton 2015, 2020). Heterodox thought, thus, maintains that fiscal deficits crowd-in private investment and private sector jobs.

More recently, from a Kaleckian point of view, Sawyer (2020) propounded that government has to maintain permanent fiscal deficits to achieve full employment. Fiscal deficits, through the multiplier process, raise income, and so, savings to the level that ensures that aggregate investment and aggregate savings are in equilibrium. In the Kaleckian viewpoint, it is the positive income effect of fiscal deficits, which filters through to increased tax receipts and savings such that real interest rates do not increase. Fiscal deficits are self-financing in the Kaleckian sense. Sawyer's (2020) argument lines up with Eisner's (1989) argument and, in terms of the overall effect on fiscal deficits on interest rates, agrees with Barro's (1989) Ricardian approach although mechanisms of adjustment differ entirely. By increasing private-sector profits, the secondary effects of the initial fiscal deficit improve private-sector job creation. Government finances initial spending by initial finance (money creation) and eventually tax revenue collections, as final finance will finance further spending. Thus, Kaleckian analysis inevitably leads to the conclusion that structural fiscal policy induces economic stagnation and rising unemployment.

Modern Monetary Theory scholarship concurs with the Kaleckian argument, and in terms of fiscal process, it has shown that government spends first before it taxes. Government, being a currency issuer, spends its currency into existence by instructing its banker to credit accounts of private firms contracted by the government to produce public goods physically (Kelton 2011, 2020). ${ }^{1}$ Alternatively, as Kalecki would have it, the government pays private service providers with securities (Sawyer 2020). Government spending is someone else's income. This means that deficit spending through the government multiplier generates new income,

1.We are aware that because of central bank independence tenets and other statutory We are aware that because of central bankindependence tenets and other statutory arrangements, the central bank is prohibited from financing government spending directly. new employment and ultimately higher levels of savings and tax revenue. The presence of slack in the economy makes this process possible. However, Newman (2020) raises an Austrian critique to MMT for failing to realise that deficit financing and monetisation of debt lead to economic stagnation and a suboptimal capital structure in the private sector.

Eisner (1989) and Kelton $(2015,2020)$, however, maintain that fiscal deficits can be too low or too high, and the real constraint that must guide the determination of the optimal level of the fiscal deficit is inflation. In most cases, therefore, too low fiscal deficits may undermine economic growth and worsen unemployment, just as too high fiscal deficits can trigger inflation. Some studies in Africa confirm that expansionary fiscal policy reduces unemployment. Obayori (2016) emphasised that rising fiscal deficits reduced unemployment, especially if the quality of public expenditure is high. Tanaka (2020), using a three-generations overlapping model, demonstrated that the elimination of structural unemployment required fiscal deficits, but once the economy attained full employment, market forces, and not further deficits, could sustain it.

Others found fiscal deficits to have mixed effects on unemployment (Gachari \& Korir 2020; Iwuoha 2020). Gachari and Korir (2020) found expansionary fiscal policy in Kenya to have an insignificant positive effect on employment. Iwuoha (2020) showed that in Nigeria, debt-financed budget deficits aggravated the unemployment problem. In light of the contradictions in the theoretical framing of the relationship between fiscal deficits and unemployment, the study has three research questions. Firstly, do fiscal deficits influence unemployment in South Africa? Secondly, do fiscal deficits influence interest rates? Thirdly, has the relationship between fiscal deficits and unemployment undergone a structural change over the years since the dawn of democracy?

\section{Research design}

Theoretically, it is possible for unemployment and fiscal deficits to co-influence each other to the extent that rising unemployment erodes the tax base and increase social security expenditures thereby increasing fiscal deficits, while fiscal deficits might reduce unemployment. Furthermore, fiscal deficits and interest rates can theoretically co-influence each other to the extent that fiscal deficits increase interest rates, while interest rates increase debt-servicing costs thus increasing fiscal deficits. The theoretical links justify the use of the vector autoregressive regression (VAR) framework, which the study employs. Because unit roots confirmed that the variables had mixed orders of integration, $\mathrm{I}(0)$ and $\mathrm{I}(1)$ (Table 1), a Toda-Yamamoto VAR estimation framework is used in the study. The Granger non-causality testing framework proposed by Toda-Yamamoto requires the lag structure to be modified such that the optimal lag length is augmented by the maximum order of integration (Toda \& Yamamoto 1995). The Granger non-causality test will focus on the optimal lag length, while the augmented lag structure whitens the error term. The VAR model is specified: 
TABLE 1: Unit root tests, intercept only.

\begin{tabular}{|c|c|c|c|c|}
\hline Variable & Levels & First difference & $\begin{array}{c}\text { Second } \\
\text { difference }\end{array}$ & $\begin{array}{c}\text { Order of } \\
\text { integration }\end{array}$ \\
\hline \multicolumn{5}{|l|}{ ADF test } \\
\hline $\begin{array}{l}\text { Unemployment } \\
\text { rate }\end{array}$ & -2.105 & $-11.241 * * *$ & - & One \\
\hline Budget deficit & -1.696 & $-4.127 * * *$ & - & One \\
\hline Prime rate & $-3.3382 *$ & $-4.232 * * *$ & - & One \\
\hline $\begin{array}{l}\text { Private investment/ } \\
\text { GDP }\end{array}$ & -1.150 & -2.297 & $-6.502 * * *$ & Two \\
\hline \multicolumn{5}{|l|}{ KPSS test } \\
\hline \multirow{2}{*}{$\begin{array}{l}\text { Unemployment } \\
\text { rate }\end{array}$} & 0.567 & 0.063 & - & Zero@ @ 1\% \\
\hline & {$[0.739 ; 0.463]$} & {$[0.739 ; 0.463]$} & - & One@ @\% \\
\hline \multirow[t]{2}{*}{ Budget deficit } & 0.206 & 0.072 & - & One \\
\hline & {$[0.216 ; 0.146]$} & {$[0.216 ; 0.146]$} & - & - \\
\hline \multirow[t]{2}{*}{ Prime lending rate } & 0.090 & - & - & Zero \\
\hline & {$[0.216 ; 0.146]$} & - & - & - \\
\hline \multirow{2}{*}{$\begin{array}{l}\text { Private } \\
\text { investment/GDP }\end{array}$} & 0.988 & 0.096 & - & One \\
\hline & {$[0.739 ; 0.463]$} & {$[0.739 ; 0.463]$} & - & - \\
\hline \multicolumn{5}{|c|}{ Breakpoint test: Break date } \\
\hline $\begin{array}{l}\text { Unemployment } \\
\text { rate }\end{array}$ & -3.383 & $-11.816 * * *$ & $\begin{array}{c}\text { 1996Q4 (levels), } \\
\text { 1998Q1(1 } 1^{\text {st }} \\
\text { difference) }\end{array}$ & One \\
\hline Budget deficit & $-8.082 * * *$ & - & 1997Q2 (levels) & Zero \\
\hline Prime lending rate & -4.165 & $-4.931 * *$ & $\begin{array}{l}\text { 2000Q4 (levels); } \\
\text { 200104 (first } \\
\text { difference) }\end{array}$ & One \\
\hline $\begin{array}{l}\text { Private } \\
\text { investment/GDP }\end{array}$ & $-4.315^{*}$ & $-14.158 * * *$ & $\begin{array}{c}200303 \text { (levels); } \\
\text { 1995Q1 (first } \\
\text { difference) }\end{array}$ & One \\
\hline
\end{tabular}

Note: $* * *$ means $p<0.01 ; * *$ means $p<0.05 ;[\ldots]$ are $1 \%$ and $5 \%$ critical values for KPSS, respectively.

ADF, Augmented Dickey-Fuller; KPSS, Kwiakowski, Phillips, Schmidt and Shin.

unemployment $_{t}=\beta_{10}+\sum_{i=1}^{p, d} \beta_{1 i}$ unemployment $_{t-j}+\sum_{j=1}^{q, d} \gamma_{1 j}$ deficit $_{t-i}+$ $\sum_{h=1}^{r, d} \alpha_{1 h}$ primerate $_{t-h}+\sum_{g}^{s, d} \varphi_{1 g}$ investment $_{t-g}+\varepsilon_{1 t}$

[Eqn 1]

deficit $_{t}=\beta_{20}+\sum_{i=1}^{p, d} \beta_{2 i}$ unemployment $_{t-j}+\sum_{j=1}^{q, d} \gamma_{2 j}$ deficit $_{t-i}+$ $\sum_{h=1}^{r, d} \alpha_{2 h}$ primerate $_{t-h}+\sum_{g}^{s, d} \varphi_{2 g}$ investment $_{t-g}+\varepsilon_{2 t}$

[Eqn 2]

primerate $_{t}=\beta_{30}+\sum_{i=1}^{p, d} \beta_{3 i}$ unemployment $_{t-j}+\sum_{j=1}^{q, d} \gamma_{3 j}$ deficit $_{t-i}+$ $\sum_{h=1}^{r, d} \alpha_{3 h}$ primerate $_{t-h}+\sum_{g}^{s, d} \varphi_{3 g}$ investment $_{t-g}+\varepsilon_{3 t}$

[Eqn 3]

Investment $_{t}=\beta_{40}+\sum_{i=1}^{p, d} \beta_{4 i}$ unemployment $_{t-j}+\sum_{j=1}^{q, d} \gamma_{4 j}$ deficit $_{t-i}+$ $\sum_{h=1}^{r, d} \alpha_{4 h}$ primerate $_{t-h}+\sum_{g}^{s, d} \varphi_{4 g}$ investment $_{t-g}+\varepsilon_{4 t}$

[Eqn 4]

The error terms $\varepsilon_{1 t}, \varepsilon_{2 t}, \varepsilon_{3 t}$ and $\varepsilon_{4 t}$ are assumed to follow a multivariate normal distribution. $d$ is the maximum order of integration, which is determined by using the standard Augmented Dickey-Fuller (ADF) test and the Kwiakowski, Phillips, Schmidt and Shin (KPSS) test that structure their null hypothesis differently. The test for Granger noncausality tests the null hypotheses that $\gamma_{1 i}=0, \alpha_{1 h}=0, \varphi_{1 q}=0$, $\beta_{2 j}=0, \alpha_{2 h}=0, \varphi_{2 g}=0, \gamma_{3 j}=0, \varphi_{3 g}=0, \beta_{3 i}=0, \beta_{4 j}=0, \gamma_{4 i}=0, \alpha_{4 h}=0$, for $\mathrm{i}=1, \ldots, \mathrm{p} ; \mathrm{j}=1, \ldots, \mathrm{q}$, and $\mathrm{h}=1 \ldots, \mathrm{r}$ and excluding the augmenting maximum lag, $\mathrm{d}$.
The causality tests revealed that unemployment and prime rate do not granger-cause fiscal deficits; hence the study proceeded to estimate an autoregressive distributed lag (ARDL) model. Fiscal deficits often have lagged effects on other economic variables. This is particularly true because of the existence of policy lags such as recognition, reaction, implementation and impact lags. Based on this motivation, an ARDL model provides an essential framework for examining the effect of fiscal deficits on unemployment. Furthermore, the ARDL model allows for modelling of both $\mathrm{I}(0)$ and $\mathrm{I}(1)$ variables in the same regression, going by the unit root test results of the Kwiatkowski-Phillips-Schmidt-Shin and structural break tests. The ARDL (p, q) model is specified as follows:

unemployment $_{t}=\beta_{0}+\sum_{i=1}^{p} \beta_{i}$ unemployment $_{t-i}+\sum_{j=1}^{q} \alpha_{j}$ deficit $_{t-j}+$ $\sum_{j=1}^{q} \vartheta_{j}$ deficit $_{t-j}^{2}+\sum_{h=1}^{r} \gamma_{h}$ primerate $_{t-h}+\sum_{g}^{s} \varphi_{g}$ investment $_{t-g}+$ $\sum_{k=1}^{m} \vartheta_{k}$ dummy $_{k}+\varepsilon_{t}$

[Eqn 5]

In equation (5), p, q, $r$ and $s$ are optimal lag lengths determined by information criteria. The error term, $\varepsilon_{t^{\prime}}$ is assumed to be identically and independently distributed with a mean of zero and a constant variance. After performing an F-bounds test for cointegration on [Eqn 5], and establishing the existence of a cointegrating relationship, an ARDL error correction representation can be estimated. The ARDL bounds test model can be specified as:

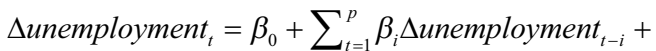

$\sum_{j=1}^{q} \alpha_{j} \Delta$ deficit $_{t-j}+\sum_{t=1}^{q} \vartheta_{j} \Delta$ deficit $_{t-q}^{2}+\sum_{h=1}^{r} \gamma_{h}$ sprimerate $_{t-h}+$

$\sum_{g}^{s} \omega_{g}$ sinvestment $_{t-g}+\varphi_{1}$ unemployment $_{t-1}+\varphi_{2}$ deficit $_{t-1}+$

$\varphi_{3}$ deficit $_{t-1}^{2}+\varphi_{4}$ primerate $_{t-1}+\varphi_{5}$ investment $_{t-1}+$

$\sum_{k=1}^{m} \vartheta_{k}$ dummy $_{k}+\varepsilon_{t}$

[Eqn 6]

The coefficients $\varphi_{1}, \varphi_{2}, \varphi_{3}, \varphi_{4}$, and $\varphi_{5}$ are error correction long-run coefficients and $\beta_{i^{\prime}} \alpha_{i^{\prime}} \vartheta_{i^{\prime}} \gamma_{h}$ and $\omega_{g}$ are short-run coefficients. The ARDL F-bounds test is applied to the joint hypothesis that $\varphi_{1}=\varphi_{2}=\varphi_{3}=\varphi_{4}=\varphi_{5}=0$. If the observed $\mathrm{F}$ exceeds the upper bound critical $F$ value of the bounds test, there is a long-run relationship; otherwise there is none.

And the ARDL error correction representation can be specified as:

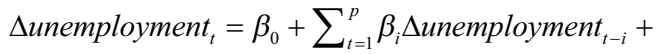

$\sum_{t=1}^{q} \alpha_{j} \Delta$ deficit $_{t-j}+\sum_{t=1}^{q} \vartheta_{j} \Delta$ deficit $_{t-q}^{2}+\sum_{h=1}^{r} \gamma_{h}$ sprimerate $_{t-h}+$

$\sum_{g}^{s} \omega_{g}$ sinvestment $_{t-g}+\theta E C T_{t-1}+\sum_{k=1}^{m} \vartheta_{k}$ dummy $_{k}+\varepsilon_{t}$

[Eqn 7]

In [Eqn 7], we replace $\varphi_{1}$ unemployment $_{t-1}+\varphi_{2}$ deficit $_{t-1}+$ $\varphi_{3}$ deficit $^{2}{ }_{t-1} \varphi_{4}$ primerate $_{t-1}+\varphi_{5}$ investment $_{t-1}$ with $\theta \mathrm{ECT}_{t-1}$ 
whereby $\theta$ is a measure of the speed of adjustment to the long run and ECT is the error correction term. For convergence to the long run, $\theta \in(-2,0)$. Dummy variables are treated as fixed regressors and control for structural breaks. Furthermore, interaction between the dummy variable MTEF and fiscal deficits is also controlled to account for interaction effects.

The data used in the article was obtained from the South African Reserve Bank's historic macroeconomic time series database. The data was quarterly for the years 1994: Q1 to 2019: Q4. Because the study presented a considerable discussion of the trends in the introduction of the article, descriptive statistics are not presented. The MTEF dummy, which takes a value of 1 for 1998Q1 to 2019Q4 and zero otherwise, is employed to capture fiscal governance beliefs, which are oriented to fiscal consolidation and conform to the expansionary fiscal contraction hypothesis largely. Two other dummies, the rand crisis taking a value of 1 for 1998Q2 to 1998Q4 and 2001Q1 to Q4 and the global financial crisis taking a value of 1 for 2008Q4 to 2009Q2, are controlled for.

\section{Results \\ Unit root tests}

The variables can be modelled within an ARDL framework given that the unit root results in Table 1 show a mixture of $\mathrm{I}(0)$ and $\mathrm{I}(1)$ variables. The ADF result for private investment/ GDP is ignored because the other two tests have a greater power of test than the standard ADF. The variables can also be estimated within a Toda-Yamamoto framework.

\section{Vector autoregressive regression and autoregressive distributed lag estimation results}

The estimated results in Table 2 and the block exogeneity Wald tests of causality in Table 3 show that fiscal deficits Granger-cause the unemployment rate and the private investment/GDP ratio, but they have no statistical influence on the prime rate. Causality runs from fiscal deficits to the unemployment rate only; there is no reverse causality unlike the theoretical expectation spelt out earlier, which works through the effect of the unemployment rate on the tax base and on social security expenditures. Fiscal deficits are weakly exogenous and all the four lags are statistically significant individually. There is bi-directional causal relationship between fiscal deficits and the private investment/GDP ratio. This conforms to theory because investment expands the tax base, thus reducing the budget deficit, while budget deficits might increase investment in the short term and worsen it in the long term. The only significant lag in the investmentdeficit regression is negative, which suggests existence of crowding-out effects of budget deficits.

Estimated results (Table 2) show that fiscal deficits cause unemployment. For the lagged third quarter, the fiscal deficit has a positive effect on unemployment, with unemployment increasing, on average, by $0.19 \%$ after an increase in fiscal deficit, other things being equal. The impulse response
TABLE 2: Toda-Yamamoto vector autoregressive regression estimation results.

\begin{tabular}{|c|c|c|c|c|}
\hline Explanatory variable & Unemployment & Deficit & Prime rate & $\begin{array}{c}\text { Private } \\
\text { investment/ } \\
\text { GDP }\end{array}$ \\
\hline Unemployment $_{\mathrm{t}-1}$ & $\begin{array}{c}0.709 * * * \\
(0.109)\end{array}$ & $\begin{array}{l}0.198 \\
(0.166)\end{array}$ & $\begin{array}{l}-0.076 \\
(0.089)\end{array}$ & $\begin{array}{c}-0.108 * * * \\
(0.035)\end{array}$ \\
\hline Unemployment $_{\mathrm{t}-2}$ & $\begin{array}{c}0.169 \\
(0.132)\end{array}$ & $\begin{array}{l}0.040 \\
(0.200)\end{array}$ & $\begin{array}{l}0.184 * \\
(0.108)\end{array}$ & $\begin{array}{l}0.071 * \\
(0.043)\end{array}$ \\
\hline Unemployment $_{\mathrm{t}-3}$ & $\begin{array}{l}-0.013 \\
(0.128)\end{array}$ & $\begin{array}{l}-0.051 \\
(0.194)\end{array}$ & $\begin{array}{l}-0.156 \\
(0.105)\end{array}$ & $\begin{array}{c}0.056 \\
(0.041)\end{array}$ \\
\hline Unemployment $_{\mathrm{t}-4}$ & $\begin{array}{l}-0.138 \\
(0.122)\end{array}$ & $\begin{array}{l}-0.103 \\
(0.185)\end{array}$ & $\begin{array}{l}-0.089 \\
(0.099)\end{array}$ & $\begin{array}{l}-0.055 \\
(0.039)\end{array}$ \\
\hline Deficit $_{t-1}$ & $\begin{array}{l}-0.075 \\
(0.109)\end{array}$ & $\begin{array}{c}0.109 \\
(0.073)\end{array}$ & $\begin{array}{l}-0.001 \\
(0.039)\end{array}$ & $\begin{array}{l}-0.005 \\
(0.016)\end{array}$ \\
\hline Deficit $_{t-2}$ & $\begin{array}{l}0.025 \\
(0.075)\end{array}$ & $\begin{array}{c}0.359 * * * \\
(0.113)\end{array}$ & $\begin{array}{l}-0.057 \\
(0.061)\end{array}$ & $\begin{array}{c}0.006 \\
(0.024)\end{array}$ \\
\hline Deficit $_{t-3}$ & $\begin{array}{c}0.193^{* * *} \\
(0.047)\end{array}$ & $\begin{array}{l}0.033 \\
(0.072)\end{array}$ & $\begin{array}{l}-0.024 \\
(0.039)\end{array}$ & $\begin{array}{c}-0.043^{* *} \\
(0.015)\end{array}$ \\
\hline Deficit $_{\mathrm{t}-4}$ & $\begin{array}{l}0.076 \\
(0.052)\end{array}$ & $\begin{array}{c}0.744 * * * \\
(0.080)\end{array}$ & $\begin{array}{l}0.064 \\
(0.043)\end{array}$ & $\begin{array}{c}0.007 \\
(0.017)\end{array}$ \\
\hline Prime rate $_{t-1}$ & $\begin{array}{l}-0.159 \\
(0.136)\end{array}$ & $\begin{array}{l}-0.173 \\
(0.205)\end{array}$ & $\begin{array}{c}1.627 * * * \\
(0.111)\end{array}$ & $\begin{array}{c}-0.091 * * \\
(0.044)\end{array}$ \\
\hline Prime rate $_{t-2}$ & $\begin{array}{c}0.263 \\
(0.262)\end{array}$ & $\begin{array}{c}0.258 \\
(0.396)\end{array}$ & $\begin{array}{c}-0.609 * * * \\
(0.213)\end{array}$ & $\begin{array}{c}0.205^{* *} \\
(0.085)\end{array}$ \\
\hline Prime rate $_{t-3}$ & $\begin{array}{l}-0.054 \\
(0.265)\end{array}$ & $\begin{array}{l}-0.104 \\
(0.401)\end{array}$ & $\begin{array}{c}0.063 \\
(0.226)\end{array}$ & $\begin{array}{c}-0.198 * * \\
(0.086)\end{array}$ \\
\hline Prime rate $_{t-4}$ & $\begin{array}{l}-0.137 \\
(0.195)\end{array}$ & $\begin{array}{l}-0.111 \\
(0.295)\end{array}$ & $\begin{array}{l}-0.246 \\
(0.159)\end{array}$ & $\begin{array}{l}0.119 * \\
(0.063)\end{array}$ \\
\hline Private investment/GDP ${ }_{t-1}$ & $\begin{array}{l}-0.204 \\
(0.334)\end{array}$ & $\begin{array}{c}0.042 \\
(0.506)\end{array}$ & $\begin{array}{c}0.420 \\
(0.272)\end{array}$ & $\begin{array}{c}0.765 * * * \\
(0.108)\end{array}$ \\
\hline Private investment/GDP $\mathrm{t}_{\mathrm{t} 2}$ & $\begin{array}{c}0.112 \\
(0.391)\end{array}$ & $\begin{array}{l}1.581^{* *} \\
(0.592)\end{array}$ & $\begin{array}{l}-0.307 \\
(0.319)\end{array}$ & $\begin{array}{c}0.030 \\
(0.127)\end{array}$ \\
\hline Private investment/GDP ${ }_{\mathrm{t}-3}$ & $\begin{array}{l}-0.401 \\
(0.382)\end{array}$ & $\begin{array}{c}-1.085^{*} \\
(0.578)\end{array}$ & $\begin{array}{l}-0.365 \\
(0.311)\end{array}$ & $\begin{array}{c}-0.281 * * \\
(0.124)\end{array}$ \\
\hline Private investment/GDP ${ }_{\mathrm{t}-4}$ & $\begin{array}{c}0.815 * * \\
(0.357)\end{array}$ & $\begin{array}{l}-0.029 \\
(0.541)\end{array}$ & $\begin{array}{c}0.180 \\
(0.291)\end{array}$ & $\begin{array}{c}0.520 * * * \\
(0.116)\end{array}$ \\
\hline Constant & $\begin{array}{l}-2.867 \\
(2.950)\end{array}$ & $\begin{array}{l}-2.021 \\
(4.464)\end{array}$ & $\begin{array}{c}3.139 \\
(2.405)\end{array}$ & $\begin{array}{c}0.797 \\
(0.954)\end{array}$ \\
\hline Unemployment $_{\mathrm{t}-6}$ & $\begin{array}{c}0.271 * * * \\
(0.108)\end{array}$ & $\begin{array}{l}-0.013 \\
(0.132)\end{array}$ & $\begin{array}{c}0.093 \\
(0.071)\end{array}$ & $\begin{array}{c}0.042 \\
(0.028)\end{array}$ \\
\hline Deficit $_{t-6}$ & $\begin{array}{l}-0.021 \\
(0.070)\end{array}$ & $\begin{array}{c}-0.319 * * * \\
(0.106)\end{array}$ & $\begin{array}{c}0.028 \\
(0.057)\end{array}$ & $\begin{array}{c}0.018 \\
(0.023)\end{array}$ \\
\hline Prime rate $_{t-6}$ & $\begin{array}{c}0.154 * * \\
(0.076)\end{array}$ & $\begin{array}{c}0.119 \\
(0.116)\end{array}$ & $\begin{array}{c}0.114 \\
(0.062)\end{array}$ & $\begin{array}{l}-0.043 \\
(0.025)\end{array}$ \\
\hline $\begin{array}{l}\text { Private investment/ } \\
\text { GDP }_{\mathrm{t}-6}\end{array}$ & $\begin{array}{l}-0.150 \\
(0.261)\end{array}$ & $\begin{array}{l}-0.205 \\
(0.394)\end{array}$ & $\begin{array}{l}-0.082 \\
(0.213)\end{array}$ & $\begin{array}{l}-0.113 \\
(0.084)\end{array}$ \\
\hline Lag structure, SIC, HQ & 4 & - & - & - \\
\hline$R^{2}$ & 0.890 & 0.822 & 0.988 & 0.930 \\
\hline Normality test, $\chi^{2},[$ prob] & $60.110[0.000]$ & - & - & - \\
\hline $\begin{array}{l}\text { Serial correlation LM test, } \\
\chi^{2},[\text { prob] at lag } 1\end{array}$ & $16.310[0.432]$ & - & - & - \\
\hline $\begin{array}{l}\text { Heteroscedasticity test, } \\
\chi^{2},[\text { prob] }\end{array}$ & $\begin{array}{c}433.456 \\
{[0.120]}\end{array}$ & $\begin{array}{l}- \\
-\end{array}$ & $\begin{array}{l}- \\
-\end{array}$ & - \\
\hline
\end{tabular}

Note: ${ }^{*}, p<0.10 ; * *, p<0.05 ; * * *, p<0.01 ;(\ldots)$ are standard errors; $[\ldots]$ are $p$-values. 
outcomes in Figure 2 also confirm that a one standard deviation increase in fiscal deficits increases the unemployment rate, and the effects persist with some plateauing tendency over time.

TABLE 3: Vector autoregressive regression Granger causality/block exogeneity Wald tests.

\begin{tabular}{lccc}
\hline Excluded & $\chi^{2}$ & Degrees of freedom & Probability \\
\hline Unemployment rate & & & \\
Deficit & 22.759 & 4 & 0.0001 \\
Prime rate & 2.674 & 4 & 0.6138 \\
Private investment & 5.846 & 4 & 0.2109 \\
All & 43.325 & 12 & 0.0000 \\
Deficit & & & \\
Unemployment rate & 2.448 & 4 & 0.6540 \\
Prime rate & 3.220 & 4 & 0.5217 \\
Private investment & 11.111 & 4 & 0.0253 \\
All & 17.199 & 12 & 0.1423 \\
Prime rate & & & \\
Unemployment rate & 7.792 & 4 & 0.0995 \\
Deficit & 3.154 & 4 & 0.5324 \\
Private investment & 3.320 & 4 & 0.5057 \\
All & 16.444 & 12 & 0.1717 \\
Private investment/GDP & & & 0.0274 \\
Unemployment rate & 10.925 & 4 & 0.0733 \\
Deficits & 8.554 & 4 & 0.0380 \\
Prime rate & 10.147 & 4 & 0.0001 \\
All & 38.266 & 12 & \\
\hline
\end{tabular}

This agrees with the view that fiscal deficits undermine growth and employment in the long run through the crowding-out effect on private investment and inflationary effect (Burger et al. 2016).

Table 2 shows that fiscal deficits do not influence the prime rate, which confirms the interest neutrality of budget deficits (Akinboade 2004; Barro 1989; Choi \& Holmes 2014; Darrat 1989). Table 3 shows that budget deficits do not granger cause the prime rate. The Ricardian explanation given by Barro (1989) suggests that a regression of interest rates on deficits would establish that deficits have a statistically insignificant effect. Mukhtar and Zakaria (2008) and Giannaros and Kolluri (1989) agree with our finding that deficits do not have any significant effect on interest rates, and that this indicates the prevalence of the interest neutrality of deficits.

While theory predicts that interest rates influence unemployment through their effect on private investment, the causality tests show that the prime lending rate does not influence unemployment in South Africa. The private investment/GDP ratio granger causes unemployment, but the effect is positive, which runs counter to expectations. However, labour economics scholarship has established that private investment in South Africa has failed to deal a durable blow on

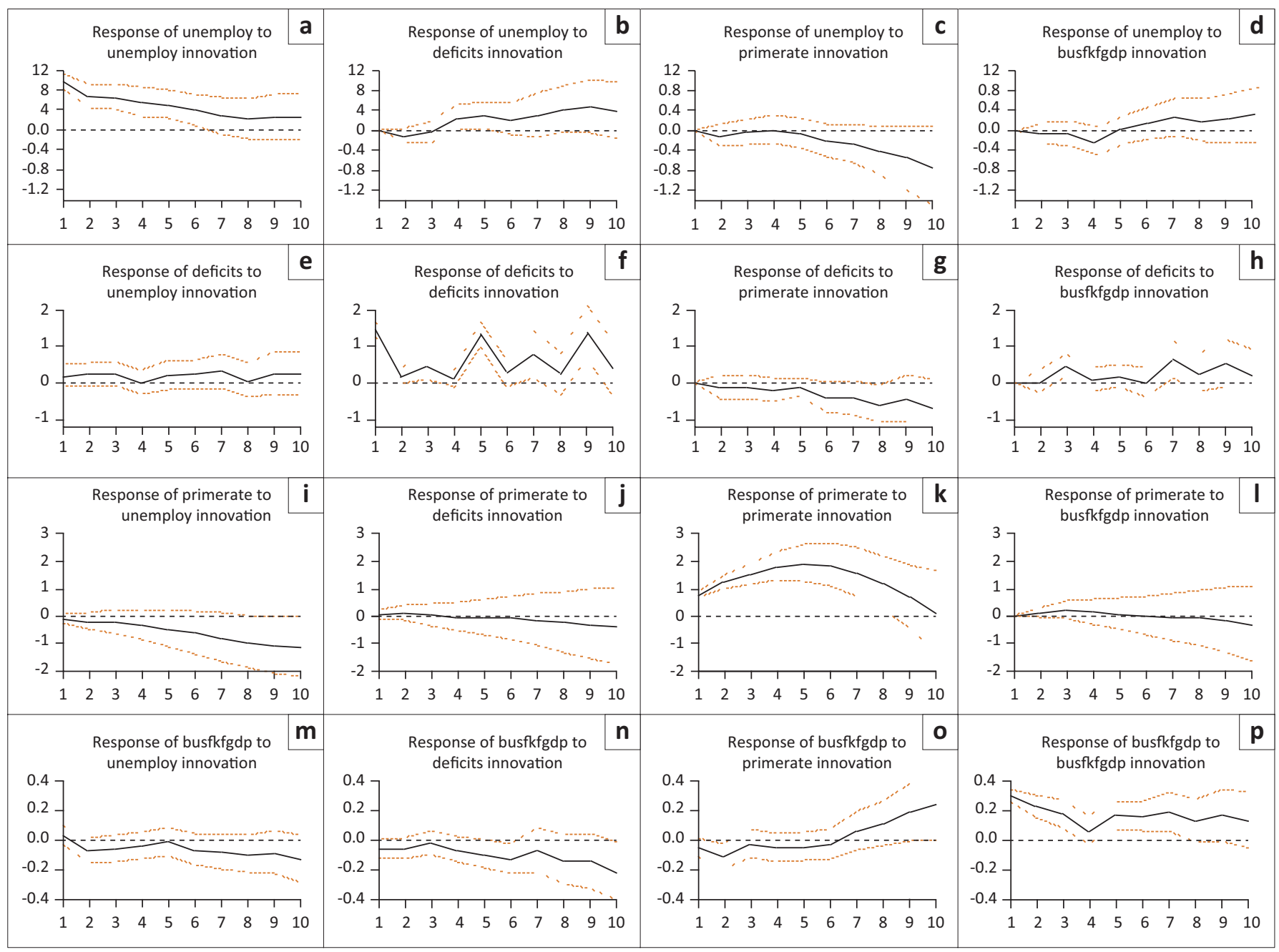

FIGURE 2: Impulse response analysis (a-p). 
unemployment because of two major phenomena - skill intensification and capital intensification (Seekings \& Nattrass 2008). This means that rising investment and unemployment can coexist unless the investment is labour intensive.

As is expected, there is a causal relationship between prime rate and investment (Table 2). The results in Table 3 show that the prime rate granger causes the private investment/ GDP ratio. Theoretically, the interest rate has a negative effect on investment. The signs of the coefficients of the prime rate up to four lags are mixed, but both positive and negative signs have a credible explanation. Under conditions of rising corporate cash holdings, such as South Africa, is experiencing (Diaw 2020; Dudley \& Zhang 2016; HuangMeier, Lambertides \& Steeley 2016; Karwowski 2015), it is not uncommon to find interest rates and private investment to have a positive relationship.

The estimates in Table 2 also reveal that unemployment granger causes the private investment/GDP ratio and mostly having a negative effect. Considering that unemployment weakens aggregate demand and so reduce the profitability of private investment, the existence of the causal relationship is credible.

From Figure 2, it is observed that unemployment responses to shocks in fiscal deficits in a cyclical fashion, plateauing at a new steady state. The cyclical behaviour also points to the lack of active labour market institutions that provide permanent super-automatic stabilisers such as job guarantees. Rather, under the current setup, aggregate demand stabilisation efforts through short-term public works programmes would naturally produce a cyclical pattern like the one in Figure 2. However, fiscal deficits do not respond to shocks in unemployment.

Because fiscal deficits are weakly exogenous, the relationship between the two variables can be represented within an ARDL modelling framework. The ARDL model results are reported in Table 4.

The results in Table 4 show that in the long run, fiscal deficits increase unemployment, which agrees with the VAR estimates in Table 2. All coefficients of fiscal deficit variables up to four lags, except the third lag that is insignificant and has a negative sign, have a positive sign. While the coefficients of the squared fiscal deficit variables for up to the second lag are positive and the deficit variables are positive, once the interaction term is considered, the relationship turns out to be a normal U-shape. This suggests that below a certain threshold, fiscal deficits reduce unemployment, but beyond the threshold deficits increase unemployment. A rough estimation by taking the first derivative of unemployment with respect to (1) fiscal deficit and (2) fiscal deficit ${ }_{t-2}$ for the case of MTEF $=1$ yields an optimal fiscal deficit of approximately $1.9 \%$ and $1.7 \%$ in the long term, respectively. With the caveat that such comparative statics should be interpreted with caution because the model does not control
TABLE 4: Autoregressive distributed lag estimation results.

\begin{tabular}{|c|c|c|}
\hline ARDL $(1,3,2,0,0,2)$ & Unemployment $_{t}$ & $\Delta$ Unemployment $_{t}$ \\
\hline \multirow[t]{2}{*}{ Unemployment $_{t-1}$} & $0.831 * * *$ & - \\
\hline & $(0.067)$ & - \\
\hline \multirow[t]{2}{*}{ Deficit $_{t}$} & $0.584 * * *$ & - \\
\hline & $(0.197)$ & - \\
\hline \multirow{2}{*}{ Deficit $_{t-1}$} & -0.176 & - \\
\hline & $(0.148)$ & - \\
\hline \multirow[t]{2}{*}{ Deficit $_{t-2}$} & $0.535 * * *$ & - \\
\hline & $(0.190)$ & - \\
\hline \multirow[t]{2}{*}{ Deficit $_{t-3}$} & $0.146 * * *$ & - \\
\hline & $(0.036)$ & - \\
\hline \multirow[t]{2}{*}{ Deficitsqd $_{t}$} & $0.019 * *$ & - \\
\hline & $(0.009)$ & - \\
\hline \multirow[t]{2}{*}{ Deficitsqd $_{t-1}$} & $0.029 * * *$ & - \\
\hline & $(0.009)$ & - \\
\hline \multirow[t]{2}{*}{ Deficitsqd $_{t-2}$} & $0.029 * * *$ & - \\
\hline & $(0.009)$ & - \\
\hline \multirow[t]{2}{*}{ Prime rate $_{\mathrm{t}}$} & -0.026 & - \\
\hline & $(0.025)$ & - \\
\hline \multirow[t]{2}{*}{ Private investment/GDP ${ }_{\mathrm{t}}$} & -0.089 & - \\
\hline & $(0.132)$ & - \\
\hline \multirow[t]{2}{*}{$\left(\mathrm{MTEF}^{*} \text { deficit }\right)_{\mathrm{t}}$} & $-0.658 * * *$ & - \\
\hline & (0.199) & - \\
\hline \multirow[t]{2}{*}{$(M T E F * \text { deficit })_{t-1}$} & -0.130 & - \\
\hline & $(0.133)$ & - \\
\hline \multirow[t]{2}{*}{$(M T E F * \text { deficit })_{t-2}$} & $-0.634 * * *$ & - \\
\hline & $(0.185)$ & - \\
\hline \multirow[t]{2}{*}{$\Delta$ Deficit } & - & $0.584 * * *$ \\
\hline & - & $(0.130)$ \\
\hline \multirow[t]{2}{*}{$\Delta$ Deficit $_{t-1}$} & - & $-0.681 * * *$ \\
\hline & - & $(0.120)$ \\
\hline \multirow[t]{2}{*}{$\Delta$ Deficit $_{\mathrm{t}-2}$} & - & $-0.146 * * *$ \\
\hline & - & $(0.032)$ \\
\hline \multirow[t]{2}{*}{$\Delta$ Deficitsqd $_{t}$} & - & $0.019 * * *$ \\
\hline & - & $(0.007)$ \\
\hline$\Delta$ Deficitsqd $_{\mathrm{t}-1}$ & - & $-0.029 * * *$ \\
\hline & - & $(0.007)$ \\
\hline$\Delta\left(\text { MTEF }^{*} \text { deficit }\right)_{\mathrm{t}}$ & - & $-0.658 * * *$ \\
\hline & - & $(0.134)$ \\
\hline$\Delta\left(\text { MTEF }^{*} \text { deficit }\right)_{\mathrm{t}-1}$ & - & $0.634 * * *$ \\
\hline & - & $(0.127)$ \\
\hline $\mathrm{MTEF}_{\mathrm{t}}$ & $7.781 * * *$ & $7.781 * * *$ \\
\hline = 1 for 1998Q1-2019Q4 & $(1.741)$ & $(1.214)$ \\
\hline 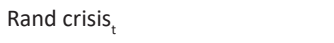 & $0.921 *$ & $0.921 * *$ \\
\hline = 1 for 1998Q1-Q4 \& 2001Q1-Q4 & $(0.488)$ & $(0.441)$ \\
\hline Global financial crisis ${ }_{t}$ & 0.423 & 0.423 \\
\hline$=1$ for $2008 Q 4-2009 Q 2$ & $(0.445)$ & $(0.395)$ \\
\hline Error correction term $\mathrm{t}_{\mathrm{t}-1}$ & - & $-0.169 * * *$ \\
\hline & - & $(0.026)$ \\
\hline Intercept & -2.780 & $-2.780 * * *$ \\
\hline & $(3.040)$ & $(0.499)$ \\
\hline$R^{2}$ & 0.903 & 0.484 \\
\hline F-stat & $49.121[0.000]$ & $7.597[0.000]$ \\
\hline F-bounds test \{critical values\} & F-stat, level of sig & $\begin{array}{l}\text { Lower bound; Upper } \\
\text { bound }\end{array}$ \\
\hline Unemployment $(1,3,2,0,0,2)$ & $6.8751 \%$ & 3.414 .68 \\
\hline & $5 \%$ & 2.623 .79 \\
\hline Normality test: $\chi^{2},[p r o b]$ & $4.399[0.111]$ & - \\
\hline Serial correlation test: $\chi^{2}$, [prob] & $2.445[0.295]$ & - \\
\hline Heteroscedasticity test: $\chi^{2},[p r o b]$ & $24.306[0.083]$ & - \\
\hline Ramsey reset test, $t$, [prob] & $0.455[0.651]$ & - \\
\hline Lag order determined by & SIC & - \\
\hline
\end{tabular}

MTEF, Medium Term Expenditure Framework; ADRL, autoregressive distributed lag. 

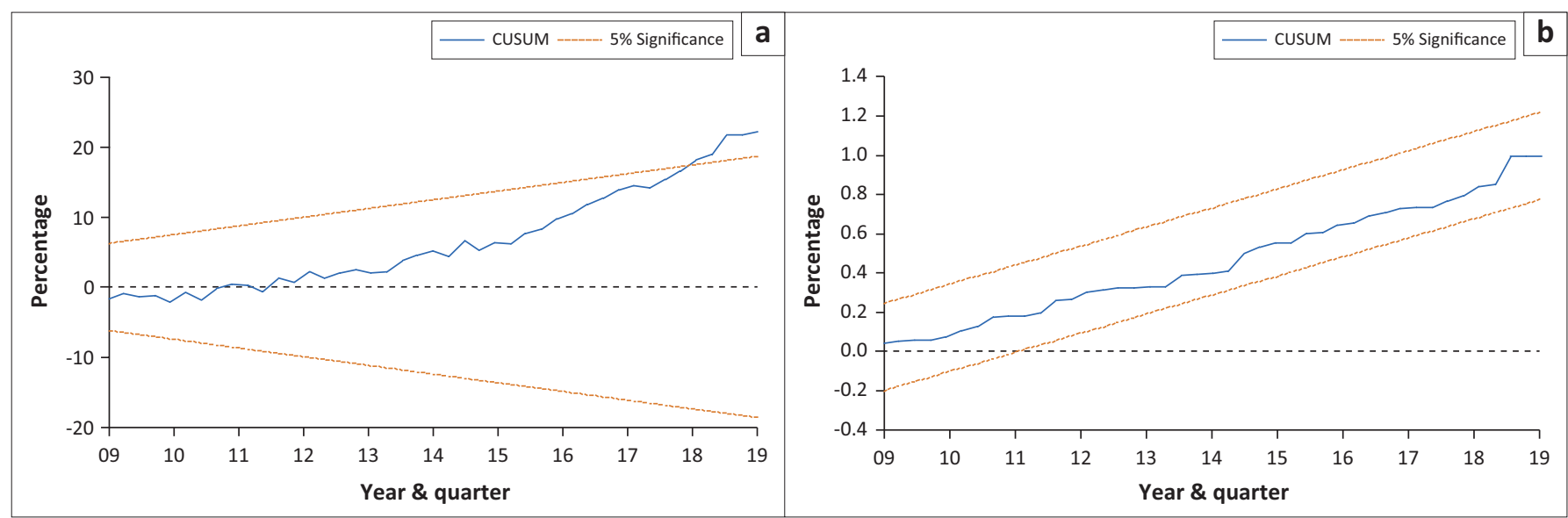

FIGURE 3: Stability test (a-b) for the unemployment-budget deficit relationship.

TABLE 5: Autoregressive distributed lag block exogeneity causality tests.

\begin{tabular}{lcl}
\hline Hypothesis & $\boldsymbol{F}$-stat $[\boldsymbol{p}$-value] & Conclusion \\
$\begin{array}{l}\text { All coefficients of deficit } \\
\text { and deficit }{ }^{2}=0\end{array}$ & $6.238[0.000]$ & $\begin{array}{l}\text { Deficits granger cause } \\
\text { unemployment }\end{array}$ \\
All coefficients of deficit ${ }^{2}=0$ & $4.925[0.003]$ & $\begin{array}{l}\text { Deficits have a non-linear } \\
\text { effect on unemployment }\end{array}$ \\
All coefficients of MTEF*deficits & $4.664[0.005]$ & $\begin{array}{l}\text { Relationship has undergone } \\
\text { structural change }\end{array}$ \\
\hline
\end{tabular}

MTEF, Medium Term Expenditure Framework.

for many other influences on unemployment, the thresholds are economically reasonable. Theoretically, a rise in fiscal deficits is expected to reduce unemployment, but beyond a certain threshold, it will undermine unemployment through the crowding-out effect on private investment as fiscal deficits increase both inflation and nominal interest rates.

Short-run coefficients in the ARDL error correction model in Table 2 suggest that fiscal deficits reduce unemployment in the short run. The intuition is economically logical because neoclassical thought shows that fiscal deficits have short-run negative effects on output and unemployment (Browne 1983; Clark 1945; Congdon, Kling \& Mullainathan 2011; Wagner 2019). The ARDL error correction model shows that the unemployment-fiscal deficit relationship is a normal U-shape for current changes, which agrees with the intuition from the ARDL model, and has an inverted U-shape for lagged changes. Comparative statics show that in the short-run fiscal deficits reduce unemployment when they are below 1.9\% (differentiating with respect to $\Delta$ deficit $_{t}$ ) and a fiscal surplus of $0.8 \%$ (differentiating with respect to $\Delta$ deficit $_{\mathrm{t}-1}$ ). Regardless of which regression is used, the thresholds are close in the case of both the ARDL error correction model and the ARDL model.

The error correction model in Table 2 shows that there is a longrun relationship between fiscal deficits and unemployment, and, thus, that fiscal deficits Granger-cause unemployment. The speed of adjustment to the long run following a shock in the relationship is about $16.9 \%$. The speed of adjustment is slow, suggesting that once a shock between fiscal deficits and unemployment occurs, it will persist for quite some time. The slow speed of adjustment suggests that there are other compounding factors that structurally determine unemployment and that fiscal deficits are not a panacea.
The interaction terms are significant, and the significance of the coefficients points to structural change in the slope coefficients. The introduction of the MTEF fiscal management framework changed the unemployment-fiscal deficit relationship. Of the three dummies, the rand crisis dummy and the MTEF dummy are significant, and the latter indicates that unemployment has been much higher since adoption of this framework, the adoption of which heralded the coming of expansionary fiscal contraction beliefs in fiscal programming.

The results do not reveal any obvious violation of the assumptions of classical regression analysis. The residuals are normally distributed. They do not suffer from serial correlation and heteroscedasticity. The Ramsey reset test suggests that the model is correctly specified. Furthermore, the estimates are stable judging by the CUSUM-squared tests reported in Figure 3.

The results reported in Table 5 also show that fiscal deficits Granger-cause unemployment in both the short run and the long run, which concurs with the findings in the TodaYamamoto test (Tables 2 and 3). Table 5 shows that the relationship between unemployment and budget deficits has undergone structural change and that deficits have a significant non-linear relationship with unemployment.

\section{Discussion}

The findings suggest that budget deficits, under the current institutional setup, at best, reduce unemployment in the short run. The finding naturally leads to a typical Keynesian demand management policy, which focuses at reducing cyclically induced unemployment. However, unemployment in South Africa seems to be involuntary largely and structural in nature (Banerjee et al. 2008; Ferreira \& Rossouw 2016; Kingdon \& Knight 2004, 2007; Schoeman \& Blaauw 2009; Simkins 2004; Thwala 2011; Vogel 2015). A short-term Keynesian aggregate demand management policy would not deliver stable jobs that the South Africa society really wants.

Burger and Calitz (2020) have argued that South Africa's government spending to GDP has gone past the optimal level of $29 \%$. Our findings suggest that the optimal level of 
the fiscal balance lies between a surplus of $0.8 \%$ and a deficit of $1.9 \%$. The existence of an optimal level of expenditure to GDP ratio suggests that there is an optimal fiscal deficit to GDP ratio, beyond which expansionary fiscal policy increases unemployment. While it cannot be claimed that the BurgerCalitz optimal level of government spending to GDP corresponds to the optimal level of fiscal deficit to GDP found in this study, there is an obvious complementarity in these two empirical claims.

Heterodox scholars explain that fiscal deficits under fiscal institutional arrangements that are pro-neoliberal tend to have the observed positive effect on unemployment because they are set up for failure already (Tcherneva 2018). To transform budget deficits such that they have a long-run effect of reducing unemployment, instituting a job guarantee programme as a permanent fiscal policy tool would reduce involuntary and structural unemployment (Tanaka 2020; Tcherneva 2018; Thwala 2011). It becomes a super automatic stabiliser. The MMT scholarship advances this proposal as an effective solution to unemployment financed by deficits. As an example, green jobs, a prototype of which is the Working for Water programme in South Africa, could become a permanent mechanism for dealing with unemployment, especially if coupled with decent wages, while restoring ecological capital and providing other care economy services. The Working for Water programme has succeeded in delivering ecological benefits, but social benefits of the programme are proving to be unsustainable, unsubstantial and sometimes the social goals have remained largely impracticable (Buch \& Dixon 2009). The Working for Water programme lacks in many ways relative to a job guarantee. For example, it pays less than decent wages offers only low-skilled and temporary jobs, and sometimes the jobs are less targeted at the most needy (Hope 2006; Turpie, Marais \& Blignaut 2008). Bek, Nel and Binns (2017) argue that the neoliberal foundation of the Working for Water programme constrains it from delivering on social objectives. Indeed, McConnachie et al. (2013) established that the focus on short-term unemployment alleviation undermines sustainable resolution of unemployment. This is because the programme is not set up as a genuine job guarantee, a permanent active labour market institution funded through budget deficits. Unfortunately, our model could not control for the type of labour market institutions, for lack of data, to be able to evaluate their interaction with fiscal deficits in influencing unemployment.

The foregoing observation naturally leads to a discussion on whether a job guarantee or a wage subsidy would be a better fiscal institutional mechanism for managing unemployment. A job guarantee is more effective, according to MMT literature, because it targets the unemployed directly, whereas a wage subsidy targets corporations (potential employers) as a way of incentivising them to employ the jobless (Kelton 2020; Mitchell \& Wray 2005; Tcherneva 2018). Wage subsidies generally fail to deliver decent and sustainable jobs (Richardson 1998; Schoer \& Rankin 2011). Other scholars found youth wage subsidies to impact youth unemployment negatively, which in another sense implies that deficit-financed wage subsidies or tax credits reduce unemployment. In that sense, the choice between a job guarantee and a wage subsidy - both being deficit-financed economic institutions - is a matter of the relative degree of effectiveness.

\section{Conclusion}

The study sets out to test the neoclassical, and MMT claims on the effect of budget deficits on unemployment. The results obtained suggest that the MMT view is supported only in the short run, but the neoclassical view seems to be supported in the long run. One of the problems that have been identified by heterodox scholarship is the temporary nature of jobs created by public works programmes that governments roll out in difficult economic times. Given the stubbornness of unemployment in South Africa, the natural course of action is to design active labour market institutions such as job guarantees that can provide a permanent fiscal solution to the problem of unemployment, which is also eroding the skills base among the youth. The findings of the study point to two broad issues. The extent to which fiscal deficits reduce unemployment depends on the ideological underpinnings of fiscal and labour market institutions - individualist or collectivist. This means that active fiscal policy is not to be constrained by policy beliefs premised on the expansionary fiscal contraction hypothesis.

\section{Acknowledgements Competing interests}

The author declares that there are no financial or personal relationships that may have inappropriately influenced him in writing this research article.

\section{Author's contributions}

I declare that I am the sole author of this research article.

\section{Ethical considerations}

This article followed all ethical standards for research without direct contact with human or animal subjects.

\section{Funding information}

The author received no financial support for the research and authorship. However, Rhodes University assisted with publication fees for this article.

\section{Data availability}

Data are available from the sources indicated in the reference list. More information is available from the author upon reasonable request. 


\section{Disclaimer}

The views and opinions expressed in this article are those of the author and do not necessarily reflect the official policy or position of any affiliated agency of the author.

\section{References}

Akinboade, O.A., 2004, 'The relationship between budget deficit and interest rates in South Africa: Some econometric results', Development Southern Africa 21(2) 289-302. https://doi.org/10.1080/0376835042000219550

Alenda-Demoutiez, J. \& Mügge, D., 2020, 'The lure of ill-fitting unemployment statistics: How South Africa's discouraged work seekers disappeared from the unemployment rate', New Political Economy 25(4), 590-606. https://doi.org/10.1 unemployment rate', New Politic

Altman, M. \& Hemson, D., 2008, The role of expanded public works programmes in halving unemployment, Human Sciences Research Council, viewed 10 June 2019, from http://repository.hsrc.ac.za/handle/20.500.11910/5819

Arestis, P. \& Sawyer, M., 2010, 'The return of fiscal policy', Journal of Post Keynesian Economics 32(3), 327-346. https://doi.org/10.2753/PKE0160-3477320301

Banerjee, A., Galiani, S., Levinsohn, J., McLaren, Z. \& Woolard, I., 2008, 'Why has unemployment risen in the new South Africa?', Economics of Transition 16(4), 715-740. https://doi.org/10.1111/j.1468-0351.2008.00340.x

Barro, R.J., 1989, 'The Ricardian approach to budget deficits', Journal of Economic Perspectives 3(2), 37-54. https://doi.org/10.1257/jep.3.2.37

Bek, D., Nel, E. \& Binns, T. 2017, 'Jobs, water or conservation? Deconstructing the green economy in South Africa's Working for Water Programme', Environmental green economy in South Africa's Working for Water Programme', Environ
Development 24, 136-145. https://doi.org/10.1016/j.envdev.2017.07.002

Bernheim, B.D., 1989, 'A neoclassical perspective on budget deficits', Journal of Economic Perspectives 3(2), 55-72. https://doi.org/10.1257/jep.3.2.55

Bhorat, H., Buthelezi, M., Chipkin, I., Duma, S., Mondi, L., Peter, C. et al., 2017, Betraya of the promise: How South Africa is being stolen, State Capacity Research Project, viewed 08 January 2019, from https://pari.org.za/betrayal-promise-report/.

Bonga-Bonga, L., 2012, 'Budget deficit and long-term interest rates in South Africa', African Journal of Business Management 6(11), 3954-3961. https://doi. org/10.5897/AJBM11.713

Browne, G., 1983, 'Fifty years of public finance', South African Journal of Economics 51(1), 134-173. https://doi.org/10.1111/j.1813-6982.1983.tb00780.x

Buch, A. \& Dixon, A.B., 2009, 'South Africa's working for water programme: Searching for win-win outcomes for people and the environment', Sustainable Development 17(3), 129-141. https://doi.org/10.1002/sd.370

Burger, P., 2010, 'The South African business cycle: What has changed?', South African Journal of Economic and Management Sciences 13(1), 26-49. https://doi. org/10.4102/sajems.v13i1.197

Burger, P., 2014, 'Facing the conundrum: How useful is the "Developmental State" concept in South Africa?', South African Journal of Economics 82(2), 159-180. https://doi.org/10.1111/saje.12030

Burger, P. \& Calitz, E., 2019, Sustainable fiscal policy and economic growth in South Africa, Stellenbosch Economic Working Papers WP 15/2019, viewed 05 August 2020, from www.ekon.sun.ac.za/wpapers/2019/wp152019.

Burger, P. \& Calitz, E., 2020, 'Covid-19, economic growth and South African Fiscal Policy', South African Journal of Economics 89(1), 1-22. https://doi.org/10.1111/ saje. 12270

Burger, P., Siebrits, K. \& Calitz, E., 2016, 'Fiscal consolidation and the public sector balance sheet in South Africa', South African Journal of Economics 84(4), 501-519. https://doi.org/10.1111/saje.12126

Burger, P., Stuart, I., Jooste, C. \& Cuevas, A., 2012, 'Fiscal sustainability and the fiscal reaction function for South Africa: Assessment of the past and future policy applications', South African Journal of Economics 80(2), 209-227. https://doi. org/10.1111/j.1813-6982.2012.01321.x

Calitz, E. \& Siebrits, K., 2003, 'Fiscal policy in the 1990s', South African Journal of Economic History 18(1-2), 50-75. https://doi.org/10.1080/10113430309511154

Choi, D.F. \& Holmes, M.J., 2014, 'Budget deficits and real interest rates: A regimeswitching reflection on Ricardian Equivalence', Journal of Economics and Finance 38(1), 71-83. https://doi.org/10.1007/s12197-011-9212-9

Clark, C., 1945, 'Public finance and changes in the value of money', The Economic Journal 55(220), 371-389. https://doi.org/10.2307/2226020

Congdon, W.J., Kling, J.R. \& Mullainathan, S., 2011, Policy and choice: Public finance through the lens of behavioral economics, Brookings Institution Press, Washington DC.

Darrat, A.F., 1989, 'Fiscal deficits and long-term interest rates: Further evidence from annual data', Southern Economic Journal 56(2), 363-374. https://doi. org/10.2307/1059215

De Leeuw, F. \& Holloway, T., 1985, 'The measurement and significance of cyclically adjusted Federal Budget and deficits', Journal of Money, Credit and Banking 17(2), 232-242. https://doi.org/10.2307/1992336

Diaw, A., 2020, 'Corporate cash holdings in emerging markets', Borsa Istanbul Review 21(2), 139-148. https://doi.org/10.1016/j.bir.2020.09.005

Dudley, E. \& Zhang, N., 2016, 'Trust and corporate cash holdings', Journal of Corporate Finance 41, 363-387. https://doi.org/10.1016/j.jcorpfin.2016.10.010

Eisner, R., 1989, 'Budget deficits: Rhetoric and reality', Journal of Economic Perspectives 3(2), 73-93. https://doi.org/10.1257/jep.3.2.73
Elson, D., 2013, 'Austerity policies increase unemployment and inequality-but don't reduce budget deficits and government borrowing', Journal of Australian Political Economy $71,130-133$.

Evans, P., 1985, 'Do large deficits produce high interest rates?', The American Economic Review 75(1), 68-87.

Fedeli, S., Forte, F. \& Ricchi, O., 2015, 'The long term negative relationship between public deficit and structural unemployment: An empirical study of OECD countries (1980-2009)', Atlantic Economic Journal 43(1), 39-54. https://doi.org/10.1007/ s11293-014-9437-z

Ferreira, L. \& Rossouw, R., 2016, 'South Africa's economic policies on unemployment: A historical analysis of two decades of transition', Journal of Economic and Financial Sciences 9(3), 807-832. https://doi.org/10.4102/jef.v9i3.72

Gachari, J.M. \& Korir, J.K., 2020, 'Effect of Fiscal Policy on unemployment in Kenya', Journal of Economics and Finance (IOSR-JEF) 11(1), 19-31.

Giannaros, D. \& Kolluri, B., 1989, 'The impact of budget deficits on real interest rates: An international empirical investigation', International Economic Journal 3(2), 17-25. https://doi.org/10.1080/10168738900080009

Hirsch, A. \& Hines, S., 2005, Season of hope: Economic reform under Mandela and Mbeki, IDRC, Ottawa.

Hofstatter, S., 2018, Licence to loot: How the plunder of Eskom and other parastatals almost sank South Africa, Penguin Random House, Cape Town.

Hope, R.A., 2006, 'Water, workfare and poverty: The impact of the working for wate programme on rural poverty reduction', Environment, Development and Sustainability 8(1), 139-156. https://doi.org/10.1007/s10668-005-1780-4

Huang-Meier, W., Lambertides, N. \& Steeley, J.M., 2016, 'Motives for corporate cash holdings: The CEO optimism effect', Review of Quantitative Finance and Accounting 47(3), 699-732. https://doi.org/10.1007/s11156-015-0517-1

Iwuoha, J.C., 2020, 'Rising unemployment in Nigeria: Public debt to the rescue?', Current Research Journal of Social Sciences 3(2), 280-290. https://doi. org/10.12944/CRJSSH.3.2.14

Karwowski, E., 2015, 'The finance-mining nexus in South Africa: How mining companies use the South African equity market to speculate', Journal of Southern African Studies 41(1), 9-28. https://doi.org/10.1080/03057070.2015.991601

Kelikume, I., 2016, 'The effect of budget deficit on interest rates in the countries of sub-Saharan Africa: A panel VAR approach', The Journal of Developing Areas 50(6), 105-120. https://doi.org/10.1353/jda.2016.0145

Kelton, S., 2011, 'Limitations of the government budget constraint: Users vs. issuers of the currency', Panoeconomicus 58(1), 57-66. https://doi.org/10.2298/ PAN1101057K

Kelton, S., 2015, 'The failure of austerity: Rethinking fiscal policy', The Political Quarterly 86, 28-46. https://doi.org/10.1111/1467-923X.12231

Kelton, S., 2020, The deficit myth: Modern monetary theory and how to build a better economy, Public Affairs, New York.

Kingdon, G.G. \& Knight, J., 2004, 'Unemployment in South Africa: The nature of the beast', World Development 32(3), 391-408. https://doi.org/10.1016/j worlddev.2003.10.005

Kingdon, G. \& Knight, J., 2007, 'Unemployment in South Africa, 1995-2003: Causes, problems and policies', Journal of African Economies 16(5), 813-848. https://doi. org/10.1093/jae/ejm016

Lama, R. \& Medina, J.P., 2019, 'Fiscal austerity and unemployment', Review of Economic Dynamics 34, 121-140. https://doi.org/10.1016/j.red.2019.02.007

Levinsohn, J. \& Pugatch, T., 2014, 'Prospective analysis of a wage subsidy for Cape Town youth', Journal of Development Economics 108, 169-183. https://doi. org/10.1016/j.jdeveco.2014.02.006

Magadlela, D. \& Mdzeke, N., 2004, 'Social benefits in the working for water programme as a public works initiative: Working for water', South African Journal of Science 100(1), 94-96.

Mahadea, D. \& Simson, R., 2010, 'The challenge of low employment economic growth in South Africa: 1994-2008, South African Journal of Economic and Management Sciences 13(4), 391-406. https://doi.org/10.4102/sajems.v13i4.92

McConnachie, M.M., Cowling, R.M., Shackleton, C.M. \& Knight, A.T., 2013, 'The challenges of alleviating poverty through ecological restoration: Insights from South Africa's “working for water" program', Restoration Ecology 21(5), 544-550. https://doi.org/10.1111/rec.12038

Mitchell, W.F. \& Wray, L.R., 2005, Full employment through a Job Guarantee: $A$ response to the critics, Centre of Full Employment and Equity University of Newcastle, Callaghan. https://dx.doi.org/10.2139/ssrn.1010149

Mukhtar, T. \& Zakaria, M., 2008, 'Budget deficits and interest rates: An empirical analysis for Pakistan', Journal of Economic Cooperation 29(2), 1-14.

National Treasury (South Africa), 2011, 'Confronting youth unemployment: Policy options for South Africa: Discussion Paper, National Treasury, viewed 10 September 2017, from https://pmg.org.za/policy-document/292/.

Newman, P., 2020, 'Modern monetary theory: An Austrian interpretation of recrudescent Keynesianism', Atlantic Economic Journal 48(1), 23-31. https://doi. recrudescent Keynesianism', Atlantic

Obayori, J.B., 2016, 'Fiscal policy and unemployment in Nigeria', The International Journal of Social Sciences and Humanities Invention 3(2), 1887-1891.

Padayachee, V., 2006, 'The development decade?: Economic and social change in South Africa, 1994-2004, HSRC Press, Cape Town.

Ribeiro, R.S. \& Lima, G.T., 2019, 'Government expenditure ceiling and public debt dynamics in a demand-led macromodel', Journal of Post Keynesian Economics 42(3), 363-389. https://doi.org/10.1080/01603477.2018.1521289 
Richardson, J., 1998, Do wage subsidies enhance employability? Evidence from Australian youth, Centre for Economic Performance London School of Economics Australian youth, Centre for Economic Performance London School of Economics
and Political Science, viewed 23 October 2020, from http://eprints.Ise.ac. uk/20280/1/Do_wage_subsidies_Enhance_Employability_Evidence_from uk/20280/1/Do_wa
Australian_Youth.pdf.

Salsman, R.M., 2017, 'The political economy of public debt: Three centuries of theory and evidence, Edward Elgar Publishing, Cheltenham.

Sawyer, M., 2020, 'Kalecki on budget deficits and the possibilities for full employment', Review of Political Economy 32(4), 548-562. https://doi.org/10.1080/09538259.2 020.1831203

Schoeman, C. \& Blaauw, P., 2009, 'Unemployment in South Africa 1970-2002: The development of a configuration concern for future employment', Journal of Economic and Financial Sciences 3(1), 87-98. https://doi.org/10.4102/jef.v3i1.348

Schoer, V. \& Rankin, N., 2011, Youth employment, recruitment and a youth-targeted wage subsidy: Findings from a South African firm level survey, World Bank, Human Development Unit, Africa Region, viewed 12 November 2019, from https:// openknowledge.worldbank.org/handle/10986/27458?locale-attribute=en

Simkins, C., 2004, 'Employment and unemployment in South Africa', Journal of Contemporary African Studies 22(2), 253-278. https://doi.org/10.1080/ cjca0258900042000230041

South African Reserve Bank, viewed 06 December 2020, from https://www.resbank. co.za/en/home/what-we-do/statistics/releases/online-statistical-query.

Tanaka, Y., 2020, 'Involuntary unemployment and fiscal policy for full-employment' Theoretical Economics Letters 10(4), 745-757. https://doi.org/10.4236/ tel.2020.104046
Tcherneva, P.R., 2018, The job guarantee: Design, jobs, and implementation, Levy Economics Institute, Working Papers Series, (902), viewed 25 June 2020, from https://www.levyinstitute.org/pubs/wp_902.pdf

Thwala, W.D., 2011, 'Public works programmes as a tool to address unemployment and skills shortages among the youth in South Africa', African Journal of Business Management 5(15), 6011-6020.

Toda, H.Y. \& Yamamoto, T., 1995, 'Statistical inference in vector autoregressions with possibly integrated processes', Journal of Econometrics 66(1-2), 225-250. https:// doi.org/10.1016/0304-4076(94)01616-8

Turpie, J.K., Marais, C. \& Blignaut, J.N., 2008, 'The working for water programme: Evolution of a payments for ecosystem services mechanism that addresses both poverty and ecosystem service delivery in South Africa', Ecological Economics 65(4), 788-798. https://doi.org/10.1016/j.ecolecon.2007.12.024

Seekings, J. \& Nattrass, N., 2008, Class, race, and inequality in South Africa, Yale University Press, New Haven.

Uxó, J., Álvarez, I. \& Febrero, E., 2018, 'Fiscal space on the Eurozone periphery and the use of the (partially) balanced-budget multiplier: The case of Spain', Journal of Post Keynesian Economics 41(1), 99-125. https://doi.org/10.1080/01603477.201 7.1376589

Vogel, P., 2015, Generation Jobless?: Turning the youth unemployment crisis into opportunity, Springer, Hampshire.

Wagner, R.E., 2019, Public debt as a form of public finance: Overcoming a category mistake and its vices, Cambridge University Press, New York.

Watts, M.J. \& Sharpe, T.P., 2013, 'Immutable laws of debt dynamics', Journal of Post Keynesian Economics 36(1), 59-84. https://doi.org/10.1017/9781108696050 